Abstracta Iranica

Revue bibliographique pour le domaine irano-aryen

Volume 32-33 | 2013

Comptes rendus des publications de 2009-2010

\title{
Jad Hatem. L'amour pur hyperbolique en mystique musulmane
}

\section{Pierre Lory}

\section{(2) OpenEdition \\ 1 Journals}

Édition électronique

URL : http://journals.openedition.org/abstractairanica/40532

DOI : 10.4000/abstractairanica.40532

ISSN : 1961-960X

\section{Éditeur :}

CNRS (UMR 7528 Mondes iraniens et indiens), Éditions de l'IFRI

\section{Édition imprimée}

Date de publication : 1 décembre 2013

ISSN : 0240-8910

\section{Référence électronique}

Pierre Lory, « Jad Hatem. L'amour pur hyperbolique en mystique musulmane », Abstracta Iranica [En ligne], Volume 32-33 | 2013, document 387, mis en ligne le 01 juillet 2016, consulté le 30 septembre 2020. URL : http://journals.openedition.org/abstractairanica/40532 ; DOI : https://doi.org/10.4000/ abstractairanica.40532

Ce document a été généré automatiquement le 29 septembre 2020.

Tous droits réservés 


\title{
Jad Hatem. L'amour pur hyperbolique en mystique musulmane
}

\author{
Pierre Lory
}

\section{RÉFÉRENCE}

Jad Hatem. L'amour pur hyperbolique en mystique musulmane. Paris, Editions du Cygne, $2009,166 \mathrm{p}$.

1 Cet essai philosophique court mais très dense confronte les paroles de mystiques musulmans sur l'amour divin à une analyse serrée. J.H. aborde le thème de l'« amour pur ", souvent représenté en islam par les célèbres vers de Rābi'a sur les deux amours et l'interprétation qu'en a fait Ġazālī. Il fait remarquer à juste titre que l'amour chez Rābi'a, si élevé qu'il soit, reste intéressé à un certain niveau: il procure un bonheur incomparable à quoique ce soit de terrestre. Le pur amour au sens radical, que J.H. nomme «hyperbolique» consiste à aimer Dieu y compris dans la déréliction, le châtiment voire la damnation. La question d'un amour absolu universel - alors même que le Coran enjoint au croyant de détester les ennemis de la foi - est également posée. Comment aimer ses propres ennemis, comment aimer les ennemis de Dieu - et surtout comment aimer de façon pure, totalement gratuite? On retrouve au fil des pages Madame Guyon et Fénelon, et bien des figures de mystique chrétienne. En islam se détachent Bisțāmī et surtout Ḥallāj, dont la figure d'Iblīs assume une attitude radicale face à la Récompense. L'abondance et la variété des références est telle qu'il est impossible de les évoquer ici. Au total, la profondeur de l'argumentation donne véritablement lieu à une nouvelle problématisation d'un thème pourtant largement connu et commenté. 


\section{AUTEURS}

PIERRE LORY

EPHE, Paris 